\title{
Reductive activity of free and immobilized cells of cyanobacteria toward oxophosphonates-comparative study
}

\author{
Monika Górak ${ }^{1}$ • Ewa Żymańczyk-Duda ${ }^{1}$
}

Received: 21 September 2015 / Revised and accepted: 25 August 2016/Published online: 15 September 2016

(C) The Author(s) 2016. This article is published with open access at Springerlink.com

\begin{abstract}
This report, based on the previous studies, compares the reductive activity of different modes of following photobiocatalysts (on laboratory and preparative scale): Arthrospira maxima, Nostoc cf. muscorum and Nodularia sphaerocarpa, toward diethyl esters of 2oxopropylphosphonate (1), 2-oxo-2-phenylethylphosphonate (2), and 2-oxobutylphosphonate (3). It was confirmed that immobilization in alginate matrix do not affect the activity and viability of the biocatalysts. Corresponding $(S)$ hydroxyphosphonates (1a-3a) were obtained with similar efficiency compared to the free-cell mode with the yield and of the optical purity e.e respectively (e.g., $N$. sphaerocarpa experiments): (1) yield: $21 \%$, e.e. $84 \%$; (2) yield $97 \%$, e.e. 97 ; (3) yield $21 \%$, e.e. $89 \%$. Scaling up the processes for the best biocatalyst, $N$. sphaerocarpa, indicated that the use of freeliving cells of cyanobacteria is more effective $(640 \mathrm{mg}$ of substrate 2, $44 \%$ of yield, $91 \%$ of e.e.), compared to the column bioreactor packed with immobilized cells of this photobiocatalyst (384 mg of substrate $2,38 \%$ of yield, $86 \%$ of e.e). In the case of free and immobilized cells of $N$. cf. muscorum, agitation of the medium was the crucial activity mediator. Shaking culture of free cells of $N$. cf. muscorum converted the diethyl 2-oxo-2-phenylethylphosphonate (2) with the yield of $43 \%$ (99\% of e.e.) compared to $18 \%$ (99\% of e.e., stationary culture). Immobilized cells of this cyanobacterium were also more active toward (2) under
\end{abstract}

Monika Górak

monika.gorak@pwr.edu.pl

Ewa Żymańczyk-Duda

ewa.zymanczyk-duda@pwr.edu.pl

1 Department of Bioorganic Chemistry, Wrocław University of Technology, Wybrzeże Wyspiańskiego 27, 50-370 Wrocław, Poland shaking conditions (28\% of yield, $99 \%$ of e.e.) than free ones without agitation.

Keywords Biotransformation - Cyanobacteria . Immobilization $\cdot$ Phosphonates

\section{Introduction}

Biocatalytic processes represent an effective and, in some cases, preferable alternative to the chemical synthesis of optically pure chiral fine chemicals. The remarkable advantages of biocatalysis are its selectivity and usual lack of side products (Faber 2011). The most significant drawback of bioconversion is the requirement of aqueous environment for most enzymatic reactions, which is a restriction for biotransformation of poorly soluble organic compounds.

Current applications of biocatalyzed processes are targeted to multiple industrial recipients such as producers of detergents, pharmaceuticals, fine chemicals, food, biofuels, or animal feed (Adrio and Demain 2014). The practicability of technological solutions based upon the enzymatic systems is often limited by the problems with the loss of catalytic activity, which is often a consequence of non-physiological process conditions or/and of the toxic impact of the xenobiotic substrate. These are solved, at least partially, by biocatalyst and reaction environment engineering. The cell or enzyme immobilization techniques protect and stabilize the fragile biological structures. As a consequence, the use of free cells in industrial processes is rather rare in comparison to immobilized cells, since it offers various advantages and financial benefits (Sayed et al. 2007).

Recently, cyanobacteria have gained attention because of their applications to bioconversions of structurally different substrates into desired, usable products. In general, 
most of immobilizations methods used for microorganisms can be introduced into cyanobacterial biotransformations. Several techniques of immobilization of these microbes have been reported in the literature (MorenoGarrido 2008), and usually, the specific procedure is matched to a defined biotechnological application. The entrapment of living cells in natural polysaccharide gels (calcium alginate, agar, carrageenan) or inside synthetic polymers (acrylamide, urethane, photo-crosslinkable resin) (Rooke et al. 2008; Ueno et al. 2008; Arabi et al. 2010) are the most frequently applied methods. Immobilized algae are mainly used for wastewater treatment (Lee et al. 2013), for removal of heavy metals (biosorption), e.g., the AlgaSORB ${ }^{\odot}$ sorption process uses algal cells immobilized in a silica gel polymer to remove heavy metal ions from aqueous solutions (Prasad et al. 2006). Entrapped cells of microalgae also have been used as biocatalyst in biotransformations of monoterpenes and steroids (Arabi et al. 2010; Rasoul-Amini et al. 2011). Immobilization efficiently protects cyanobacteria against direct contact with the organic solvent (Perullini et al. 2014). Such a form of biocatalyst is used in culture collection handling. This method is cheaper and a more readily available approach in the cultivation of microalgae (Gaudin et al. 2006). Cyanobacteria possess unique and interesting features among the photosynthetic microorganisms applied for energy conversion applications. Some efforts have also been made to produce electricity, using the cyanobacterium Nostoc sp. as a photobiocatalyst immobilized on carbon nanotubes on the anode of photobioelectrochemical cells (Sekar et al. 2014).

This paper is focused on the application of the immobilized cells of cyanobacteria as biocatalyst for a preparative scale reduction of $\beta$-oxoalkylphosphonates. Different from other possible solutions, cyanobacteria represent a diverse and unusual catalytic ability to transform $\beta$-oxoalkylphosphonates. Previously described biotransformations of $\beta$-oxophosphonates present the effective use of free cells of photoautotrophic microorganisms as whole-cell biocatalysts for the synthesis of chiral (S)-2-hydroxyalkylphosphonates (Górak and Żymańczyk-Duda 2015). Hydroxyphosphonates are a class of organophosphorus compounds with possible biological activity - they represent a synthetic platform for further applications (e.g., aminophosphonic acids and their derivatives) (Yokomatsu et al. 2003; Kolodiazhnyi 2006). The species, Nodularia sphaerocarpa, showed diverse and unusual biocatalytic ability to reduce the $\beta$-oxophosphonates, which manifests, among others, as the capacity to reduce substrate toward which other biocatalysts were non-active (Żymańczyk-Duda et al. 2000; Żurawiński et al. 2001). However, these processes allowed product formation only as a result of bioconversions carried out in closed vessels without the possibility of feeding and reusing them. The inhibition properties of phosphonate derivatives (toward many enzymes) as well as scaling up the bioreactions and biocatalysts reusing are the restrictive steps. To overcome these, the cells of biocatalysts, Arthrospira maxima, Nostoc cf. muscorum, and N. sphaerocarpa, were immobilized by entrapment method, using sodium alginate as supporting material.

This paper reports a new approach, which allowed the production of optically pure diethyl $\beta$-hydroxyphosphonates on the larger scale. The aim of this study was to invent the effective immobilization method for the oxo-xenobiotics- $\beta$ oxoalkylphosphonates enantioselective reduction. Thus, several efforts have been undertaken to optimize the entrapment process to obtain a stable culture of immobilized cells as well as a stable structure of alginate beads for bioreactor applications. To confirm the possibility of application of free-living and immobilized cells of $N$. sphaerocarpa in the preparative scale batch culture and a continuous-flow photobioreactor, appropriate experiments were conducted.

\section{Materials and methods}

\section{Chemicals}

All chemicals were purchased from commercial suppliers: Sigma, Aldrich, Fluka, Avantor Performance Materials Poland S.A.

\section{Synthesis of substrates}

The substrates, diethyl 2-oxopropylphosphonate (96\%; obtained from chloroacetone), diethyl 2-oxo-2-phenylethylphosphonate (97\%; obtained from 2-bromoacetophenone), diethyl 2oxobutylphosphonates (96\%; obtained from 1-bromo-2butanone), were synthesized according to standard procedure described in literature (Ryglowski and Kafarski 1996).

Chloroacetone ( $54 \mathrm{mmol}$ ) was mixed with saturated aqueous solution of sodium iodide $(54 \mathrm{mmol})$ and methanol. The mixture was stirred for $24 \mathrm{~h}$ at room temperature, methanol was evaporated under reduced pressure, and $20 \mathrm{~mL}$ of water was added. The iodoketone was extracted with two portions of chloroform $(2 \times 30 \mathrm{~mL})$. The combined extracts were dried over magnesium sulfate. To iodoacetone (or 2bromoacetophenone or 1-bromo-2-butanone) equimolar quantity of triethyl phosphite were added dropwise maintaining temperature at $5{ }^{\circ} \mathrm{C}$. The mixture was left overnight at room temperature and the volatile components of the reaction were removed on a rotary evaporator. The crude product was purified by means of column chromatography on silica gel using ethyl acetate as eluent. 


\section{Microorganisms}

Axenic strains of Arthrospira maxima (CCALA 27), Nodularia sphaerocarpa (CCALA 114), and Nostoc cf. muscorum (CCALA 129) were from the Culture Collection of Autotrophic Organisms (CCALA) of the Institute of Botany of the Academy of Sciences of the Czech Republic.

\section{Culture conditions}

All species were cultivated in 250-mL Erlenmeyer flasks containing $100 \mathrm{~mL}$ of a suitable medium. Nodularia sphaerocarpa was grown on BG-11 medium (pH 7.0) (Rippka et al. 1979), $N$. cf. muscorum was grown on BG-11 medium without $\mathrm{NaNO}_{3}$ (pH 7.0), and A. maxima on Spirulina medium (pH 9.5) (Aiba and Ogawa 1977). All species of cyanobacteria were cultivated under continuous illumination at 7-12 $\mu \mathrm{mol}$ photons $\mathrm{m}^{-2} \mathrm{~s}^{-1}$ (Power Glo fluorescent bulb, $8 \mathrm{~W}$, Hagen) at $28^{\circ} \mathrm{C}( \pm 1)$ under stationary conditions. Power Glo fluorescent bulb illuminates with bluish white light. The experiments were conducted under sterile conditions.

\section{Cell immobilization by gel entrapment}

The cyanobacteria entrapped in alginate beads were prepared using 21-day-old cultures of cyanobacterial strains. Cells were harvested by centrifugation at $1788 \times g$ at $17{ }^{\circ} \mathrm{C}$ for $20 \mathrm{~min}$. Then, the cells of $N$. sphaerocarpa and A. maxima were suspended in $5 \mathrm{~mL}$ of BG-11 medium and distilled water, respectively, whereas the cells of $N$. cf. muscorum were suspended in 10-mL BG-11 medium without $\mathrm{NaNO}_{3}$. Cyanobacterial cells were mixed homogenously with equal volume of a sodium alginate solution ( 2 or $4 \%, w / v)$ for $20 \mathrm{~min}$, to obtain a final concentration of 1 and $2 \%(w / v)$ of alginate/cells mixture. Then, the mixture was dropped into cold solution of $\mathrm{CaCl}_{2} \cdot 2 \mathrm{H}_{2} \mathrm{O}(0.2 \mathrm{M})$ by syringe, forming gel beads with diameters between 2.0 and $3.0 \mathrm{~mm}$. Pump pressure and a needle gauge were used to control the bead size. The beads were incubated at room temperature for $1 \mathrm{~h}$. Then, the alginate beads were washed with distilled water, placed in $\mathrm{BaCl}_{2} \cdot 2 \mathrm{H}_{2} \mathrm{O}$ solution $(0.85 \%)$ for $15 \mathrm{~min}$, rinsed again with distilled water and then with medium suitable for tested cyanobacterial strain. The produced $\mathrm{Ca}$-alginate beads were cultured in fresh and sterile medium. Immobilized cells of $N$. sphaerocarpa and $N$. cf. muscorum were cultivated on BG-11 and BG-11 without $\mathrm{NaNO}_{3}$, respectively. Alginate-entrapped cells of A. maxima were suspended in sterile, distilled water.

\section{General procedure of $\beta$-oxoalkylphosphonates bioreduction}

Immobilized cells After immobilization, the alginateentrapped cells were incubated in 100-mL Erlenmeyer flasks containing $50 \mathrm{~mL}$ of a suitable medium and $2 \mathrm{mM}$ of the substrate (20 mg of compounds 1 and 3 and $26 \mathrm{mg}$ of compound 2).

Free-living cells The cyanobacteria were cultivated under continuous illumination (Power Glo lamp) at $31^{\circ} \mathrm{C}( \pm 1)$ under shaking $(70 \mathrm{rpm})$ conditions. After 21 days of precultivation, $1 \mathrm{mM}$ of substrate ( $20 \mathrm{mg}$ of compounds 1 and 3 and $26 \mathrm{mg}$ of compound 2) was added to the culture of cyanobacteria $(100 \mathrm{~mL})$.

The bioconversions were carried out for 7 days, at $31{ }^{\circ} \mathrm{C}$ $( \pm 1)$, under shaking $(70 \mathrm{rpm})$ conditions and under continuous bluish white light (Power Glo). Experiments were completed by the biomass removing by filtration -in the case of immobilized cells or by centrifugation $(2800 \times g, 25 \mathrm{~min}$, $17^{\circ} \mathrm{C}$ ) of free cells of cyanobacteria. Finally, the supernatants were extracted twice with $50 \mathrm{~mL}$ of ethyl acetate. Subsequently, collected organic layers were dried over anhydrous $\mathrm{MgSO}_{4}$ and evaporated under reduced pressure. The resulting oils were analyzed.

The control experiments were carried out in culture medium without as well as the biocatalysts and the substrate.

The conversion degrees of the substrates and the optical purity of the products were evaluated using the NMR technique. Each experiment was replicated in parallel at least three times.

\section{Preparative biotransformations of diethyl 2-oxo-2-phenylethylphosphonate (2)}

Immobilized cells For continuous flow column experiments, a preparative scale glass bioreactor of 40-cm length and 2-cm internal diameter was used. The bioreactor was packed with immobilized cells of $N$. sphaerocarpa (33 cm height). Biomass obtained from ten cultures of $N$. sphaerocarpa $(10 \times 100 \mathrm{~mL})$ was immobilized by gel entrapment $(2 \%(w /$ v) of sodium alginate). The BG-11 medium $(150 \mathrm{~mL})$ with $10 \mathrm{mM}$ (384 mg) of diethyl 2-oxo-2-phenylethylphosphonate (2) was pumped from a reservoir into the reactor at $4 \mathrm{~mL} \mathrm{~min}^{-1}$ flow rates with the help of a peristaltic pump. The bioprocess was conducted for 5 days under photoperiod of $16 \mathrm{~h} / 8 \mathrm{~h}$ (day/ night) provided by natural daylight intensity at $27{ }^{\circ} \mathrm{C}( \pm 1)$ in growth room. Experiments were carried out in June and July 2014 (Wrocław, $51^{\circ} 06^{\prime} 36^{\prime \prime} \mathrm{N}, 17^{\circ} 01^{\prime} 20^{\prime \prime} \mathrm{E}$ ). At regular intervals $(24 \mathrm{~h})$, eluents were collected and the presence of diethyl 2-hydroxy-2-phenylethylphosphonate (2a) in these fractions was detected.

Free-living cells Nodularia sphaerocarpa was cultivated in 2000-mL Erlenmeyer flasks containing 500-mL BG-11 medium, under continuous illumination provided by Power Glo fluorescent bulb, at $31{ }^{\circ} \mathrm{C}( \pm 1)$ under shaking conditions (70 rpm). After 21 days of precultivation, $5 \mathrm{mM}(640 \mathrm{mg})$ of 
compound 2 was added to the culture. The experiments were completed after 7 days.

\section{Optical purity assignment}

The mixtures of bioconversion products were analyzed by ${ }^{31} \mathrm{P}$ NMR spectroscopy. Spectra were recorded on Bruker Avance 600 instrument operating at $600 \mathrm{MHz}$, and measurements were made in $\mathrm{CDCl}_{3}(99.5$ at \% D) at temperature of $298 \mathrm{~K}$.

The optical purity of the products was estimated using quinine as a chiral solvating agent, which allowed achieving a shift difference of ${ }^{31} \mathrm{P}$ NMR signals coming from the hydroxyphosphonate-bioreduction products (ŻymańczykDuda et al. 1996).

The degree of the conversion of the substrate was expressed as a percentage (\%) and defined as

conversion $=\frac{P P}{P P+P S} \times 100 \%$,

where $P P$ and $P S$ are the areas under the signals observed on the ${ }^{31} \mathrm{P}$ NMR spectrum, coming from product and substrate of bioconversion, respectively.

Optical purity was computed also from the ${ }^{31} \mathrm{P}$ NMR spectrum following the formula:

e.e. $=\frac{E 1-E 2}{E 1+E 2} \times 100 \%$,

where $E 1$ and $E 2$ are the values of the area under the signals coming from the major and minor enantiomer of the product, respectively.

\section{Spectroscopic data}

Diethyl 2-oxopropylphosphonate (1) ${ }^{31} \mathrm{P}$ NMR $(600 \mathrm{~Hz}$, $\left.\mathrm{CDCl}_{3}\right) \delta 19.74 ;{ }^{1} \mathrm{H}$ NMR $\left(600 \mathrm{~Hz}, \mathrm{CDCl}_{3}\right) \delta 1.34(\mathrm{t}, 6 \mathrm{H}$, $\left.J=7.1 \mathrm{~Hz}, \mathrm{P}(\mathrm{O})\left(\mathrm{OCH}_{2} \mathrm{CH}_{3}\right)\right), 2.33\left(\mathrm{~s}, 3 \mathrm{H}, \mathrm{CH}_{3} \mathrm{C}(\mathrm{O})\right), 3.1$ (d, $\left.2 \mathrm{H}, J=22.9 \mathrm{CH}_{2} \mathrm{P}\right), 4.1-4.2\left(\mathrm{~m}, 4 \mathrm{H}, \mathrm{m}, \mathrm{P}(\mathrm{O})\left(\mathrm{OCH}_{2} \mathrm{CH}_{3}\right)\right.$ ).

Diethyl 2-hydroxypropylphosphonate (1a) ${ }^{31} \mathrm{P}$ NMR $\left(600 \mathrm{~Hz}, \mathrm{CDCl}_{3}\right) \delta 30.11 ;{ }^{1} \mathrm{H} \mathrm{NMR}\left(600 \mathrm{~Hz}, \mathrm{CDCl}_{3}\right) \delta 1.30$ $\left(\mathrm{dd}, 3 \mathrm{H}, J=6.1, J=2.2, \mathrm{CH}_{3} \mathrm{C}(\mathrm{OH})\right), 1.35(\mathrm{t}, 6 \mathrm{H}, J=7.1 \mathrm{~Hz}$, $\left.\mathrm{P}(\mathrm{O})\left(\mathrm{OCH}_{2} \mathrm{CH}_{3}\right)\right), 1.9-1.98\left(\mathrm{~m}, 2 \mathrm{H}, \mathrm{CH}_{2} \mathrm{P}\right), 3.55(\mathrm{~s}, 1 \mathrm{H}$, $\mathrm{C}(\mathrm{OH})), 4.08-4.25\left(\mathrm{~m}, 4 \mathrm{H}, \mathrm{P}(\mathrm{O})\left(\mathrm{OCH}_{2} \mathrm{CH}_{3}\right)\right)$.

Diethyl 2-oxo-2-phenylethylphosphonate (2) ${ }^{31} \mathrm{P}$ NMR $\left(600 \mathrm{~Hz}, \mathrm{CDCl}_{3}\right) \delta 20.58 ;{ }^{1} \mathrm{H}$ NMR $\left(600 \mathrm{~Hz}, \mathrm{CDCl}_{3}\right) \delta 1.29$ $\left(\mathrm{t}, 6 \mathrm{H}, J=7.0 \mathrm{~Hz}, \mathrm{P}(\mathrm{O})\left(\mathrm{OCH}_{2} \mathrm{CH}_{3}\right)\right), 3.65(\mathrm{~d}, 2 \mathrm{H}, J=22.7$, $\left.\mathrm{CH}_{2} \mathrm{P}\right), 4.15\left(\mathrm{~m}, 4 \mathrm{H}, \mathrm{P}(\mathrm{O})\left(\mathrm{OCH}_{2} \mathrm{CH}_{3}\right)\right), 7.3-7.6(\mathrm{~m}, 5 \mathrm{H}$, $\mathrm{C}_{6} \mathrm{H}_{5}$ ).
Diethyl 2-hydroxy-2-phenylethylphosphonate (2a) ${ }^{31} \mathrm{P}$ NMR $\left(600 \mathrm{~Hz}, \mathrm{CDCl}_{3}\right) \delta 29.76$;

${ }^{1} \mathrm{H}$ NMR $\left(600 \mathrm{~Hz}, \mathrm{CDCl}_{3}\right) \delta 1.29(\mathrm{t}, 6 \mathrm{H}, J=7.1$, $\left.\mathrm{P}(\mathrm{O})\left(\mathrm{OCH}_{2} \mathrm{CH}_{3}\right)\right), 2.14-2.28\left(\mathrm{~m}, 2 \mathrm{H}, \mathrm{CH}_{2} \mathrm{P}\right), 4.05-4.20(\mathrm{~m}$, $\left.4 \mathrm{H} \mathrm{P}(\mathrm{O})\left(\mathrm{OCH}_{2} \mathrm{CH}_{3}\right)\right), 5.07-5.14(\mathrm{~m}, 1 \mathrm{H}, \mathrm{C}(\mathrm{OH}) H), 7.25-$ $7.43\left(\mathrm{~m}, 5 \mathrm{H}, \mathrm{C}_{6} \mathrm{H}_{5}\right)$.

Diethyl 2-oxobutylphosphonate (3) ${ }^{31} \mathrm{P}$ NMR $(600 \mathrm{~Hz}$, $\left.\mathrm{CDCl}_{3}\right) \delta 20.08 ;{ }^{1} \mathrm{H}$ NMR $\left(600 \mathrm{~Hz}, \mathrm{CDCl}_{3}\right) \delta 1.04$ (t, $3 \mathrm{H}$, $\left.J=7.2 \mathrm{~Hz}, \mathrm{CH}_{3} \mathrm{CH}_{2} \mathrm{C}(\mathrm{O})\right), 1.31(\mathrm{t}, 6 \mathrm{H}, J=7.0 \mathrm{~Hz}$, $\left.\mathrm{P}(\mathrm{O})\left(\mathrm{OCH}_{2} \mathrm{CH}_{3}\right)\right), 2.65$ (q, $\left.2 \mathrm{H}, J=7.2 \mathrm{~Hz}, \mathrm{CH}_{3} \mathrm{CH}_{2} \mathrm{C}(\mathrm{O})\right)$, $3.06\left(\mathrm{~d}, 2 \mathrm{H}, \mathrm{CH}_{2} \mathrm{P}, J=22.8 \mathrm{~Hz}\right), 4.05-4.19(\mathrm{~m}, 4 \mathrm{H}$, $\left.\mathrm{P}(\mathrm{O})\left(\mathrm{OCH}_{2} \mathrm{CH}_{3}\right)\right)$.

Diethyl 2-hydroxybutylphosphonate (3a) ${ }^{31} \mathrm{P}$ NMR $\left(600 \mathrm{~Hz}, \mathrm{CDCl}_{3}\right) \delta 30.81 ;{ }^{1} \mathrm{H} \mathrm{NMR}\left(600 \mathrm{~Hz}, \mathrm{CDCl}_{3}\right) \delta 0.95$ (t, $\left.3 \mathrm{H}, J=7.2 \mathrm{~Hz}, \mathrm{CH}_{3} \mathrm{CH}_{2} \mathrm{C}(\mathrm{O})\right), 1.33(\mathrm{t}, 6 \mathrm{H}, J=7.0 \mathrm{~Hz}$, $\left.\mathrm{P}(\mathrm{O})\left(\mathrm{OCH}_{2} \mathrm{CH}_{3}\right)\right), 1.49-1.62\left(\mathrm{~m}, 2 \mathrm{H}, \mathrm{CH}_{3} \mathrm{CH}_{2} \mathrm{CH}(\mathrm{OH})\right)$, 1.82-2.00 (m, $\left.2 \mathrm{H}, \mathrm{CH}_{2} \mathrm{P}\right), 2.22(\mathrm{~s}, 1 \mathrm{H}, \mathrm{CH}(\mathrm{OH})), 3.56$ (s, $1 \mathrm{H}, \mathrm{CH}(\mathrm{OH})), 4.06-4.18\left(\mathrm{~m}, 4 \mathrm{H}, \mathrm{P}(\mathrm{O})\left(\mathrm{OCH}_{2} \mathrm{CH}_{3}\right)\right)$.

\section{Purification of diethyl 2-hydroxyphosphonates (1a, 2a, 3a)}

Diethyl 2-hydroxyphosphonates were purified by reversedphase pressure liquid chromatography $(\mathrm{C} 18$ - reversed phase silica gel, partial size $15-25 \mu \mathrm{m}$, pore size $100 \AA$ ) using a mixture of water-acetonitrile (10:2) as an eluent, flow rate of $3 \mathrm{~mL} \mathrm{~min}{ }^{-1}$.

\section{Determination of absolute configuration of diethyl 2-hydroxyphosphonates (1a, 2a, 3a)}

Absolute configuration of diethyl 2-hydroxyphosphonates (1a, 2a, 3a) were determined according to the procedure previously described (Górak and Żymańczyk-Duda 2015).

\section{Results}

\section{Immobilized cells vs. free cells of cyanobacteria}

This paper presents the comparative study of reductive activity of immobilized and free cells of cyanobacteria. To overcome the inhibition properties of oxophosphonates toward enzymatic systems of the cells, biocatalysts were immobilized. The concentration of the applied solutions of sodium alginate was 2 and $4 \%$ and the final concentrations of alginate in the prepared beads were 1 and $2 \%$, respectively. First of all, microalgal beads containing a final concentration of $2 \%(w / v)$ of alginate were used as biocatalysts, but in this case, a decrease of conversion of substrates compared to the process with free cells, cultivated under shaking (70 rpm) condition, was observed (Table 1). It is possible that high 
Table 1 Results of 7 days of biotransformation of $\beta$-oxoalkyl phosphonates to the corresponding diethyl 2-hydroxyphosphonates by free-living and alginate entrapped cells of cyanobacteria, under shaking conditions. Substrates: 1 = diethyl 2-oxopropylphosphonate; $2=$ diethyl 2-oxo-2-phenylethylphosphonate; 3 = Diethyl 2-oxobutylphosphonate

\begin{tabular}{|c|c|c|c|c|c|c|c|c|c|c|}
\hline \multirow[t]{2}{*}{ Substrate } & & \multicolumn{3}{|c|}{ N. sphaerocarpa } & \multicolumn{3}{|c|}{ N. cf. muscorum } & \multicolumn{3}{|c|}{ A. maxima } \\
\hline & & Free & $1 \%$ & $2 \%$ & Free & $1 \%$ & $2 \%$ & Free & $1 \%$ & $2 \%$ \\
\hline \multirow[t]{2}{*}{1} & conversion $(\%)$ & $25 \pm 1$ & $14 \pm 3$ & $21 \pm 4$ & - & - & - & $16 \pm 1$ & $>5$ & $>5$ \\
\hline & enantiomeric excess $(\%)$ & $93 \pm 2$ & $93 \pm 1$ & $84 \pm 5$ & & & & $\geq 99$ & & \\
\hline \multirow[t]{2}{*}{2} & conversion $(\%)$ & $99 \pm 0.5$ & $97 \pm 1$ & $95 \pm 1$ & $43 \pm 2$ & $28 \pm 1$ & $25 \pm 2$ & - & - & - \\
\hline & enantiomeric excess $(\%)$ & $96 \pm 0.5$ & $97 \pm 0.5$ & $95 \pm 1$ & $\geq 99$ & $\geq 99$ & $\geq 99$ & & & \\
\hline \multirow[t]{2}{*}{3} & conversion $(\%)$ & $27 \pm 2$ & $21 \pm 3$ & $20 \pm 4$ & - & - & - & - & - & - \\
\hline & enantiomeric excess $(\%)$ & $93 \pm 0.5$ & $89 \pm 4$ & $82 \pm 2$ & & & & & & \\
\hline
\end{tabular}

- no reaction

concentration of alginate caused limitations in the substrateimmobilized biocatalyst contact. The application of $1 \%(w / v)$ of alginate for bead preparation did not affect the cell viability, and this solution was slightly more effective compared to the activity of the cells entrapped in the matrix made of $2 \%$ alginate (except from N. sphaerocarpa and substrate 1) (Table 1). Experiments with beads containing ultimately $0.5 \%(w / v)$ of alginate were not performed, because even $1 \%(w / v)$ of initial concentration of sodium alginate resulted in weak beads, and in some cases, the leaking of cells was observed (Arabi et al. 2010).

Among the tested cyanobacterial strains, the application of entrapped cells of $N$. sphaerocarpa resulted in a slight decrease of the conversion of $\beta$-oxophosphonates. Nodularia sphaerocarpa cells entrapped in alginate beads were efficient toward compound 2 . The degree of conversion and the optical purity of the product diethyl (S)-2-hydroxy-2phenylethylphosphonate were up to $97 \%$ in the case of beads with $1 \%(w / v)$ alginate concentration. Transformations of aliphatic substrates 1 and 3, by immobilized cells of this strain, were less effective compared to the processes using free-living cells (Table 1); degrees of conversion were 21 and $20 \%$, respectively, in the case of the use of entrapping beads with $2 \%(w / v)$ of alginate concentration.

$\mathrm{Ca}^{2+}$-alginate-entrapped cells of cyanobacteria exhibit comparable or slightly lower catalytic activity compared to free cells of cyanobacteria, cultured under shaking conditions (Table 1). The use of the agitation, in the case of free cells of cyanobacteria, contributed to the increase of the conversion degree of substrates, since it improves the interaction between the substrate and biocatalyst. This was observed especially in the case of free cells of $N$. cf. muscorum, where shaking conditions improved the conversion of diethyl 2-oxo-2phenylethylphosphonate (2) to $43 \%$ (Table 1), compared to experiments carried out under stationary conditions where the degree of conversion was up to $18 \%$. In this particular case, the entrapped cells were more efficient biocatalysts than were the free ones cultivated under stationary conditions (Tables 1 and 2). Entrapped cells of $N$. cf. muscorum (beads containing 1 and $2 \%$ of final concentration of alginate) were able to convert substrate 2 with similar yield with a conversion degree of 25 and $28 \%$, respectively, which represents a good result, considering the possibility of reusing the biocatalyst cells.

In the case of bioreduction of aliphatic substrate, diethyl 2oxobutylphosphonate (3), carried out under shaking conditions with the free cells of $N$. sphaerocarpa, no improvement in the conversion degree was observed, compared to the stationary process. However, agitation improved the optical purity of diethyl 2-hydroxybutylphosphonate (3a)-e.e. of this product was up to $93 \%$. This is indirect proof that the activity of the enzymatic system involved in such bioreduction depends on light availability. Such mechanism was observed in previously described studies.

Immobilized biomass of A. maxima exhibited the lowest biocatalytic ability to reduce $\beta$-oxophosphonates; the degree of conversion was up to $5 \%$. In the case of free cells of A. maxima, shaking conditions did not influence the effectiveness of the process, compared to the stationary conditions, and the conversion degree was $16 \%$ (99\% of e.e.).

\section{Preparative bioreduction of substrate 2 by Nodularia sphaerocarpa}

Appropriate tests were conducted to evaluate the possibility of the application of free-living and immobilized cells of $N$. sphaerocarpa in preparative scale batch culture and in a continuous-flow photobioreactor. The application of a preparative scale continuous flow bioreactor packed with immobilized cells of $N$. sphaerocarpa achieved $38 \%$ of conversion degree and $86 \%$ of optical purity of the diethyl $(S)$-2-hydroxy-2phenylethylphosphonate (2a) within the 5-day process. In the case of the $500-\mathrm{mL}$ batch culture of free cells of $N$. sphaerocarpa, the conversion degree was $44 \%$ (91\% of e.e. of $2 a$ ) with the higher final amount of substrate $2(5 \mathrm{mM}, 540 \mu \mathrm{L}, 640 \mathrm{mg})$. 


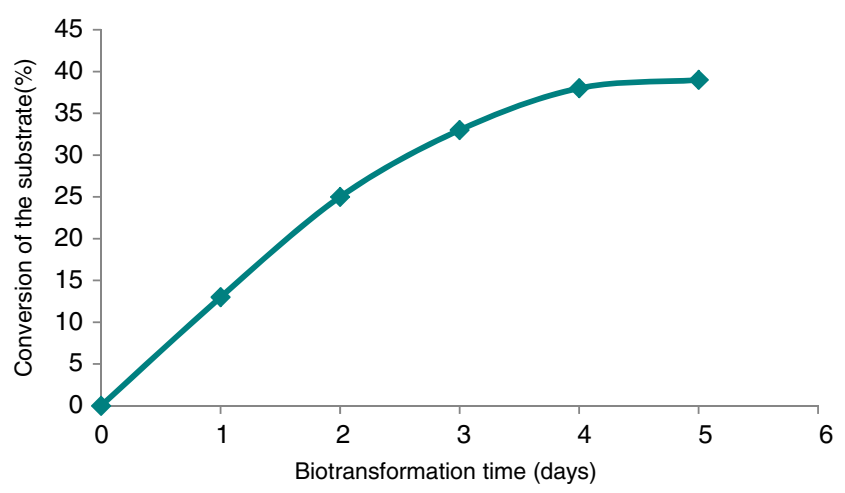

Fig. 1 The efficiency of bioreduction of compound 2 during the biotransformation process, in the case of the column bioreactor packing with immobilized cells of $N$. sphaerocarpa

To evaluate the correlation between the reaction progress and the duration of bioconversion, in the case of the column packed bioreactor, appropriated experiments were conducted. Results indicated that the largest increase of conversion degree is observed within the first $48 \mathrm{~h}$ of the biotransformation process (Fig. 1).

\section{Discussion}

Previously published results present a new biocatalytic approach to the effective use of photoautotrophic microorganisms as biocatalysts for the synthesis the chiral $(S)$-2hydroxyphosphonates under stationary conditions (Górak and Żymańczyk-Duda 2015). In contrast to other biological systems, cyanobacteria represent unusual catalytic ability to reduce $\beta$-oxoalkylphosphonates and the effectiveness of such reaction strongly depends on the structure of the substrates. Regardless of the conditions used (source of light, photoperiod, cultivation medium), the filamentous cyanobacterium A. maxima was a source of reductive activity only toward aliphatic diethyl 2-oxopropylphosphonate (1) (20\% of yield, $99 \%$ of e.e.), while $N$. cf. muscorum applied as biocatalyst

Table 2 Results of biotransformation of $\beta$-oxoalkylphosphonates by free cells of cyanobacteria under stationary (Górak and ŻymańczykDuda 2015) and shaking conditions. Substrates: $1=$ diethyl 2- allowed diethyl (S)-2-hydroxy-2-phenylethylphosphonate (2a) to be obtained with high enantiomeric excess (99\%) and $26 \%$ of conversion degree (Table 2). Nodularia sphaerocarpa was able to reduce the aromatic diethyl 2-oxo2-phenylethylphosphonate (2); the conversion degree was $99 \%$, and the optical purity of the product, diethyl (S)-2-hydroxy-2-phenylethylphosphonate, was $93 \%$, under stationary conditions (Table 2). However, previously described results show that the productivity of such a reaction system is affected by substrate concentrations where the degree of conversion of substrate 2 slightly decreases with increasing substrate concentration, but the enantioselectivity of the process and the cell viability remain almost at the same level as confirmed by flow cytometry studies (Górak and Żymańczyk-Duda 2015). These results form the basis for further experiments on scaling-up the processes and to determine if the alteration of the biocatalyst mode allows sustaining the activity of its enzymatic system under particular conditions (higher substrate concentrations). Thus, cyanobacterial cells were entrapped in an alginate matrix, one of the most widely used techniques for immobilization achieved by the physical entrapment of organisms inside a polymeric matrix. This can form a structure with optimized mechanical strength, rigidity, and porosity properties. A major advantage of alginate gel entrapment is that immobilized cells are not exposed to extreme physical-chemical condition changes during the immobilization process, as is observed in the case of immobilization in silica gel (sol-gel technique) (Rangsayatorn et al. 2004). The permeability and low toxicity of the formed matrix creates a gentle environment for the immobilized cells. The concentration of sodium alginate and calcium chloride affects the gelation mechanism and determines the mechanical behavior of alginate gels and their surface morphology (Abdel Hameed 2007). Such a procedure of immobilization seems to be appropriate, because the structure of beads was stable and the elution of cyanobacterial cells from the outer layer of beads was not observed. To evaluate the effect of immobilization on the catalytic activity of biocatalysts, the effectiveness of

oxopropylphosphonate; 2 = diethyl 2-oxo-2-phenylethylphosphonate; 3 $=$ Diethyl 2-oxobutylphosphonate

\begin{tabular}{|c|c|c|c|c|c|c|c|}
\hline \multirow[t]{2}{*}{ Substrate } & & \multicolumn{2}{|c|}{ N. sphaerocarpa } & \multicolumn{2}{|c|}{ N. cf. muscorum } & \multicolumn{2}{|l|}{ A. maxima } \\
\hline & & stationary & shaking & stationary & shaking & stationary & shaking \\
\hline \multirow[t]{2}{*}{1} & conversion $(\%)$ & $17 \pm 2$ & $25 \pm 1$ & \multirow[t]{2}{*}{-} & \multirow[t]{2}{*}{-} & $16 \pm 3$ & $16 \pm 1$ \\
\hline & enantiomeric excess $(\%)$ & $93 \pm 2$ & $93 \pm 2$ & & & $\geq 99$ & $\geq 99$ \\
\hline 2 & $\begin{array}{l}\text { conversion }(\%) \\
\text { enantiomeric excess }(\%)\end{array}$ & $\begin{array}{l}99 \pm 0.3 \\
93 \pm 1\end{array}$ & $\begin{array}{l}99 \pm 0.5 \\
96 \pm 0.5\end{array}$ & $\begin{array}{l}18 \pm 5 \\
\geq 99\end{array}$ & $\begin{array}{l}43 \pm 2 \\
\geq 99\end{array}$ & - & - \\
\hline 3 & $\begin{array}{l}\text { conversion }(\%) \\
\text { enantiomeric excess }(\%)\end{array}$ & $\begin{array}{l}27 \pm 3 \\
80 \pm 1\end{array}$ & $\begin{array}{l}27 \pm 2 \\
93 \pm 0.5\end{array}$ & - & - & - & - \\
\hline
\end{tabular}

- no reaction 
bioconversion carried out with free-living cells of cyanobacteria (under shaking conditions) and with immobilized cells was compared.

$\mathrm{Ca}^{2+}$-alginate-entrapped cells of cyanobacteria transform $\beta$-oxoalkylphosphonates to the corresponding $(S)$ hydroxyphosphonates. The presented study demonstrates that alginate-immobilized cells of $N$. sphaerocarpa, A. maxima, and $N$. cf. muscorum exhibited slightly lower reductive activity toward the $\beta$-oxophosphonates in comparison to free cells of the cyanobacteria cultured under shaking condition (Tables 1 and 2). This effect also can be related to the limited amount of light penetrating through the beads which affects the activity of the algal enzymatic system.

As it was shown (Table 1), the influence of the concentration of sodium alginate on the photobiocatalyst activity depends on the cyanobacterial species but the differences in effectiveness are small. Therefore, this cannot be considered as a crucial factor.

A very interesting phenomenon was observed in the case of bioreduction of aliphatic diethyl 2-oxopropylphosphonate (1) by $N$. sphaerocarpa; better results were achieved for cells entrapped in $2 \%$ alginate ( $21 \%$ of conversion degree ( $84 \%$ of e.e.)) than in the case of using the beads containing ultimately $1 \%(w / v)$ of alginate (14\% of conversion degree $(93 \%$ of e.e.)). This is probably associated with the structure of substrate 1 , whose moiety is the smallest one and as a consequence, its diffusion across the $2 \%$ alginate membrane is better than in the cases of the other substrates, thus facilitating the biocatalyst-substrate contact. Additionally, the interaction between the converted compound and the biocatalysts is longer in the case of the $2 \%$ matrix compared to the $1 \%$ one, simply because of the diffusion differences as diffusion is easier for beads built with $1 \%$ alginate gel. Considering the other cases, the application of $1 \%$ matrix is more effective than the $2 \%$ one, and this is probably also associated with diffusion differences.

In the case of $N$. cf. muscorum, immobilized cells of this species were more efficient than were the free cells cultivated under stationary condition but less effective when shaken culture of free cells of $N$. cf. muscorum was used. Thus, the best result was as follows: $43 \%$ of conversion degree and $99 \%$ of optical purity of the (S)-2-hydroxy-2-phenylethylphosphonate (2a). This suggests the crucial role of agitation for $N$. cf. muscorum application. Agitation allowed the avoidance of photoinhibition and self-shading effect and improves the availability of the substrate to biocatalyst.

Among the tested cyanobacterial strains, the immobilized biomass of A. maxima exhibited the lowest biocatalytic ability to reduce $\beta$-oxophosphonates within the experimental period ( 7 days) where the degree of conversion was up to $5 \%$. This is probably due to the adverse effects of the immobilization on cell viability and catalytic activity as well as on the availability of the substrate to biocatalyst, regardless of the concentration of alginate. That is why the applied procedure of the immobilization of A. maxima cells was modified, because the application of Spirulina medium as suspension and biotransformation medium resulted in the partial disintegration of structure of supporting matrixes. In the case of media containing EDTA, phosphate, and other cations (e.g., Spirulina medium), calcium cations required for proper matrix formation can be sequestered by soluble anions or be substituted by monovalent cations. This results in destabilization of the structure, leading to leakage of algal cells (Hertzberg and Jensen 1989). To avoid this problem, the Spirulina medium was replaced by distilled water, such as in the case of the alginate-entrapped cells of $S$. platensis used in biosorption processes (Duda-Chodak et al. 2013). The structure of the matrixes was stable; however, the release of photosynthetic pigments was observed, indicating cell damage. It is possible that the concentration of the cyanobacterial cells used for immobilization purposes was too high - the value of $\mathrm{OD}_{750}$ of 21 days of culture of A. maxima was 1.6. The initial cell concentration seems to be very important. It was shown that the higher initial cellular density allows a higher final cell density, stable cultures, and more efficient bioprocess to be obtained. On the other hand, too high concentration of cyanobacterial cells entrapped in alginate beads reduce the amount of light penetrating through the beads and enhance the self-shading effects, which limit the metabolic activities of the algal cells. The low catalytic activity of the entrapped cells of A. maxima can also result from the deficiency of nutrients observed within the 7-day process of biotransformation. Unfortunately, the application of distilled water instead of Spirulina medium resulted in the loss of the cellular activity.

Immobilization procedure and alginate concentration did not affect the results only in the case of use of $N$. sphaerocarpa (except for substrate 1). This, previously described as an effective free-cell biocatalyst able to reduce the $\beta$-oxophosphonates (Górak and Żymańczyk-Duda 2015), is the unique species, because of its proven resistance to increasing concentrations of converted xenobiotic substrates. This was a good starting base for further scaling up experiments with the use of N. sphaerocarpa.

Previous approaches included experiments with the substrate concentration increasing while maintaining the same volume of the culture of biocatalyst and resulted in decreasing the conversion degree of diethyl 2-oxo-2phenylethylphosphonate (2) with increasing substrate concentration. Enantioselectivity as well as cell viability remained almost at the same level (Gorak and Żymańczyk-Duda 2015). Thus, current efforts involve 
an increase in both values and were also focused on creating the economic system that allows reuse of biocatalyst.

Biotransformation processes for the best biocatalyst, $N$. sphaerocarpa, on the preparative scale indicated that the use of free-living cells of cyanobacteria is more effective (640 mg of substrate 2, $44 \%$ of yield, $91 \%$ of e.e.) and provides the suitable reaction condition and viability of biocatalyst compared to the column bioreactor packed with immobilized cells of $N$. sphaerocarpa (384 mg of substrate $2,38 \%$ of yield, $86 \%$ of e.e.). However, such solution with column bioreactor, allows reduction of the volume of required biotransformation medium from 1000 to $150 \mathrm{~mL}$ and also allows a significant increase in the substrate concentration to $10 \mathrm{mM}(300 \mu \mathrm{L} / 384 \mathrm{mg})$, so this is a more economical solution than others (batch culture). However, if the conversion degree, optical purity of the products, and the value of the substrate concentration are considered, the best results were obtained for the process carried out in the $500-\mathrm{mL}$ batch culture of free cells of $N$. sphaerocarpa.

An important observation is that the results obtained for the $500-\mathrm{mL}$ batch culture of free cells of $N$. sphaerocarpa are in the range of 35-59\% of conversion degree and are comparable to those which were obtained in the case of use the 6 and $4 \mathrm{mM}$ concentration of substrate 2 , for laboratory-scale preparations $(100 \mathrm{~mL})$ (Górak and Żymańczyk-Duda 2015). We conclude that the applied physical-chemical conditions of batch culture are close to the optimal ones, which were worked out in the laboratory-scale experiments.

In the case of the column packed bioreactor, the correlation between the reaction progress and the duration of bioconversion shows that with over time, the efficiency of bioreduction decreased (Fig. 1) and the largest increase of conversion degree is reached within the first $48 \mathrm{~h}$. Such a phenomenon is a consequence of the self-shading effects in the column packed with immobilized cells resulting in the limitation access to the light, which seems to be crucial for the biocatalytic activity of $N$. sphaerocarpa cells. However, the viability of the cells remains almost at the same level, which in turn is the next indirect evidence that enzymatic systems involved in the phosphonate conversion are a part of secondary metabolic pathways and are not vital for the survival of microbial cells.

This study for the first time reports successful scaling up the whole-cell biocatalyzed conversion of prochiral oxophosphonates. What is also important is that this study showed that there is the possibility to reuse the immobilized cells of a photobiocatalyst. Thus, the application of two different approaches, $500-\mathrm{mL}$ batch culture and continuous column bioreactor, resulted in obtaining the desired, chiral product ( $S$ )-2-hydroxy-2phenylethylphosphonate (2a) with good yield and satisfactory optical purity. The cells of $N$. sphaerocarpa remain metabolically active after completing the reduction of diethyl 2-oxo-2-phenylethylphosphonate (2). This is a good starting point for its further applications.

Acknowledgment This work was financed by a statutory activity subsidy from the Polish Ministry of Science and Higher Education for the Faculty of Chemistry of Wrocław University of Technology.

\section{Compliance with ethical standards}

Conflict of interest The authors declare that they have no competing interests.

Open Access This article is distributed under the terms of the Creative Commons Attribution 4.0 International License (http:// creativecommons.org/licenses/by/4.0/), which permits unrestricted use, distribution, and reproduction in any medium, provided you give appropriate credit to the original author(s) and the source, provide a link to the Creative Commons license, and indicate if changes were made.

\section{References}

Abdel Hameed MS (2007) Effect of algal density in bead, bead size and bead concentrations on wastewater nutrient removal. Afr J Biotechnol 6:1185-1191

Adrio JL, Demain AL (2014) Microbial enzymes: tools for biotechnological processes. Biomolecules 4:117-139

Aiba S, Ogawa T (1977) Assessment of growth yield of a blue-green alga Spirulina platensis in axenic and continuous culture. J Gen Microbiol 102:179-182

Arabi H, Tabatabaei Yazdia M, Faramarzi MA (2010) Influence of whole microalgal cell immobilization and organic solvent on the bioconversion of androst-4-en-3,17-dione to testosterone by Nostoc muscorum. J Mol Catal B 62:213-217

Duda-Chodak A, Wajda , Tarko T (2013) The immobilization of Arthrospira platensis biomass in different matrices - a practical application for lead biosorption. J Environ Sci Health A 48:509-517

Faber K (2011) Biotransformations in organic chemistry. Springer, Berlin

Gaudin P, Lebeau T, Robert JM (2006) Microalgal cell immobilization for the long-term storage of the marine diatom Haslea ostrearia. J Appl Phycol 18:175-185

Górak M, Żymańczyk-Duda E (2015) Application of cyanobacteria for chiral phosphonates synthesis. Green Chem 17:4570-4578

Hertzberg S, Jensen A (1989) Studies of alginate-immobilized marine microalgae. Bot Mar 32:267-273

Kolodiazhnyi OI (2006) Chiral hydroxy phosphonates: synthesis, configuration and biological properties. Russ Chem Rev 75:227-253

Lee Y, Hu H-F, Ch'iu CY (2013) Using agar-alginate immobilized cyanobacteria (Dermocarpella sp.) arranged in tubular chains to treat swinefarm waste water. J Appl Phycol 25:1747-1752

Moreno-Garrido I (2008) Microalgae immobilization: current techniques and uses. Bioresour Technol 99:3949-3964

Perullini M, Durrieu C, Jobbágy M, Bilmes SA (2014) Rhodamine B doped silica encapsulation matrices for the protection of photosynthetic organisms. J Biotechnol 184:94-99

Prasad BB, Banerjee S, Lakshmi D (2006) An AlgaSORB column for the quantitative sorption of arsenic (III) from water samples. Water Qual Res J Can 41:190-197 
Rangsayatorn N, Pokethitiyook P, Upatham ES, Lanza GR (2004) Cadmium biosorption by cells of Spirulina platensis TISTR 8217 immobilized in alginate and silica gel. Environ Int 30:57-63

Rasoul-Amini S, Fotooh-Abadi E, Ghasemi Y (2011) Biotransformation of monoterpenes by immobilized microalgae. J Appl Phycol 23: 975-981

Rippka R, Herdman M, Stanier RY (1979) Generic assignments, strain histories and properties of pure cultures of cyanobacteria. J Gen Microbiol 111:1-61

Rooke JC, Leonard A, Su B-L (2008) Targeting photobioreactors: immobilisation of cyanobacteria within porous silica gel using biocompatible methods. J Mater Chem 18:1333-1341

Ryglowski A, Kafarski P (1996) Preparation of 1-aminoalkylphosphonic acids and 2-aminoalkylphosphonic acids by reductive amination of oxoalkylphosphonates. Tetrahedron 52:10685-10692

Sayed M, Hameed A, Ebrahim O (2007) Biotechnological potential uses of immobilized algae. Int J Agr Biol 9:183-192

Sekar N, Umasankar Y, Ramasamy RP (2014) Photocurrent generation by immobilized cyanobacteria via direct electron transport in photo-bioelectrochemical cells. Phys Chem Chem Phys 16:7862-7871
Ueno R, Wada S, Urano N (2008) Repeated batch cultivation of the hydrocarbondegrading, micro-algal strain Prototheca zopfii RND16 immobilized in polyurethane foam. Can J Microbiol 54: 66-70

Yokomatsu T, Murano T, Akiyama T, Koizumi J, Shimeno H, Tsuji Y, Soeda S, Shimeno H (2003) Synthesis of non-competitive inhibitors of sphingomyelinases with significant activity. Bioorg Med Chem Lett 13:229-236

Żurawiński R, Nakamura K, Drabowicz J, Kiełbasiński P, Mikołajczyk M (2001) Biocatalytic synthesis of chiral non-racemic 2hydroxyalkanephosphonates. Tetrahedron Asymmetry 12:31393145

Żymańczyk-Duda E, Kafarski P, Lejczak B (2000) Reductive biotransformation of diethyl $\beta-, \gamma$ - and $\delta$-oxoalkylphosphonates by cells of baker's yeast. Enzym Microb Technol 26:265-270

Żymańczyk-Duda E, Skwarczyński M, Lejczak B, Kafarski P (1996) Accurate assay of enantiopurity of 1-hydroxy- and 2hydroxyalkylphosphonate esters. Tetrahedron Asymmetry 7:12771280 